\title{
MODEL OF CIVIC EDUCATION LEARNING BASED ON THE LOCAL WISDOM FOR REVITALIZING VALUES OF PANCASILA
}

\author{
Bambang Sumardjoko and Muhamad Musyiam \\ Universitas Muhammadiyah Surakarta \\ email: bs131@ums.ac.id
}

\begin{abstract}
The objectives of this study are to describe the existing civic education learning, develop the model of civic education learning, and measure the effectiveness of the model of civic education learning based on the local wisdom. This research and development study was carried out in three stages, i.e., preliminary study, development, and model effectiveness test. The data in this study were collected through interview and observation. The results of the research are, first, there are strength, weaknesses, chances, and obstacles in civic education learning. Second, the development of the model of civic education learning based on the local wisdom is presented in the form of the syntax of learning model through the practice of cooperative learning of Problem Based Learning and Value Clarification. Third, the model of civic education learning can be categorized as "effective" based on the criteria of validity, practicality, and effectiveness. The model of civic education learning based on the local wisdom is able to improve the score of character and nation identity by $80 \%$ and the mastery learning at least $75 \%$.
\end{abstract}

Keywords: effectiveness of learning model, local wisdom, civics learning

\section{MODEL OF CIVIC EDUCATION LEARNING BASED ON THE LOCAL WISDOM FOR REVITALIZING VALUES OF PANCASILA (bahasa Indonesia)}

\begin{abstract}
Abstrak: Tujuan penulisan ini untuk mendeskripsikan pemataan pembelajaran PKn yang tengah berlangsung selama ini, pengembangan model pembelajaran PKn, dan efektivitas model pembelajaran PKn berbasis kearifan lokal. Data diperoleh melalui penelitian pengembangan, dimulai dari studi pendahuluan, pengembangan, dan uji efektivitas model. Hasil penelitian sebagai berikut, pertama, dalam pembelajaran PKn terdapat kekuatan, kelemahan, peluang, dan ancaman. Kedua, pengembangan model pembelajaran PKn berbasis kearifan lokal dikemas dalam sintak model pembelajaran, melalui praktik pembelajaran kooperatif Problem Based Learning dan Value Clarification. Ketiga, model pembelajaran PKn tergolong efektif berdasarkan kriteria kevalidan, kepraktisan, dan keefektifan. Model pembelajaran PKn berbasis kearifan lokal mampu meningkatkan skor karakter dan jati diri bangsa sebesar $80 \%$ serta ketuntasan belajar sekurang-kurangnya $75 \%$.
\end{abstract}

Kata kunci: efektivitas model pembelajaran, kearifan lokal, pembelajaran PKn

\section{INTRODUCTION}

The Law of National Education System of the Republic of Indonesia Number 20 of 2003 article 3 states that "National education has a function to develop the capability and form the character and civilization of the dignified nation in order to educate the nation's life, aiming to develop the potency of learner to being a human, who has a belief and fear to the Almighty God, noble, healthy, knowledgeable, capable, creative, independent, and become a democratic and responsible citizen". Civic education is one of the instruments to achieve those objectives of national education.
Civic education teaches learners to be good and responsible citizens based on the values and foundations of Pancasila. Thus, civic education is essentially the praxis education of Pancasila. Epistemologically, Civic education and Pancasila is an integrated knowledge system, which has a mission to foster the potency of learners to have "civic intelligence", "civic participation", and "civic responsibility" (Winatapura, 2001). This means that the Civic education has a function to advance as well as form a good Indonesian citizen, particularly in the context of the character and civilization building of Indonesian based on the values of Pancasila. 
Pancasila is the foundation of the state and the nation's way of life. Therefore, the study of the implementation of Pancasila through civic education learning becomes important. There are several reasons; first, Pancasila is a systematic value, which requires its implementation in the daily life. Second, the implementation of Pancasila could be done through various ways; one of them is through education. Third, the content of Pancasila, which is socialized to the citizens, could be used to establish the national identity. Fourth, the content of Pancasila in civic education still faces weaknesses in terms of learning methods. Fifth, Pancasila, which has various status, meaning, and interpretation, requires a clear structuration and organization as a material of civic education. Winarno (2017) stated there is no current specific study that analyzes and formulates the material of Pancasila in civic education, in which Pancasila is imparted as the core of civic education.

The systemic framework of civic education in Indonesia is built based on a paradigm that the civic education curricular is designed as a learning subject that aims to develop the potency of individuals to become Indonesian citizens who have a noble character, intelligent, participative, and responsible. Therefore, the study of civic education can be done theoretically and programmatically (Budimansyah, 2008). Theoretically, civic education is designed as a learning subject that contains cognitive, affective, and psychomotor dimensions, which are confluent or mutually penetrating and integrated with the context of the objectives, values, concepts, and morals of Pancasila, democratic citizenship, and state defense. Programmatically, civic education is designed as a subject of learning that emphasizes the substance of the content, which carries the content of embedding values and learning experiences in the form of various behaviors that need to be realized in the daily life.

Several competencies are needed in Civic education learning. Budimansyah (2008) suggests a number of required competencies encompassing the mastery of knowledge, the development of intellectual and participatory abilities, the development of character and mental attitude, as well as a commitment to the values and basic principles of constitutional democracy. Three main components need to be studied in Civic education learning based on those competencies that must be developed, that are civic knowledge, civic skills, and civic dispositions. This means that the mission of Civic education as character education essentially aims to prepare the learners to be smart and good citizens who mastering the knowledge, skills, and values, which could be used to enhance the sense of nationality and love to the homeland.

Furthermore, the practice of education and learning indicates the degradation of the local values and local wisdom, which have been eroded by the flow of global education. Such conditions result in the diminution of etiquette, ethics, and creativity of the student. The education is considered not able to generate a quality graduate as the excellent Indonesian man. The decline of morality and values in the collective life of nation may be caused by the decrease of understanding and implementation of the noble values of Pancasila.

The phenomena in the educational field show the symptom of a desire to refuse the civic learning that merely presents moral values. Civic education learning is considered to have lost their academic characteristics because of the absence of adequate scientific theories. Civics education learning is considered to be more emphasizing the interests of certain political regimes with formalistic learning materials. The learning process does not encourage the ability of learners to be able to think critically. The process of civic education causes saturation because of the learning material tends to monotone, theoretical, cognitivist and even literalistic (Samsuri, 2009). The above phenomenon shows the determinant factors that cause the civic education learning be less interesting, firstly, the learning material tends to be literalistic over the moral values of Pancasila as civic virtues. Secondly, civic learning models tend to be cognitive memorization. Based on the above phenomena, it is necessary to find a solution for those problems so the civic education learning could become more interesting and liked by learners. One of the solutions is through the development of the model of civic education learning based on local wisdom.

Local wisdom is the values that live in society, which is believed to be true and become a reference in the daily behavior of the local community. According to Geertz (1963), the local wisdom is an entity that determines the 
dignity of a human within a society. The local wisdom contains elements of intelligence, creativity, and local knowledge of the elite and the community that would determine the development of civilization. The local wisdom is often conceptualized as local knowledge and local genius. In the recent theoretical development, the local wisdom tends to correlate with the contingent product of power relations in the society (Kalb, 2006).

Education based on the local wisdom is an educational model or strategy that has a high relevance for the development of life skills with a focus on empowering skills and local potential in each region. Learning materials have meaning and high relevance to the society empowerment based on the reality they face in the daily life. The curriculum is prepared in accordance with the environmental condition, learner's interest, learner condition, and attention to sociological and cultural obstacles. The education based on the local wisdom is education that teaches learners to embrace the concrete situation that they face in their daily life.

One of the results of the education based on the local wisdom could be in form of the knowledge that describes attitudes and behavior that reflect the local-original culture. In the case of Surakarta, the local-original culture is the Javanese culture. The wisdom values of Javanese culture such as gotong royong or mutual cooperation, tepo seliro or tolerance, and solidarity are good values which should be imparted to the students in the school. Javanese culture is a source of the moral of citizenship. In a nation-state, the strong-binding rule in form of the moral of citizenship is needed, besides of the basic rights of citizens. The moral of citizenship is a life guideline of citizens, which could help the citizens to judge right or wrong actions.

Without any intention to undermining the role of other ethnic cultural communities that supporting the diversity in unity of Indonesia, the Javanese culture and its moral values are interesting to be studied. For example, the idiom 'ojo dumeh' that could be meant that the people should not be arrogant despite having a high position. Unfortunately, such idiom, which has a moral value of Javanese culture, is no longer popular among the Javanese people, even some of them are not recognized it (Rahyono, 2009). Besides, it can be a moral source of the citizen; the Javanese culture also could become a source to develop the civic culture. The excavation of Javanese culture aims to prove that there are universal values inside of Javanese culture, which could be accepted comprehensively by the Indonesian people and served as a strategy to achieve the objective of civic education learning that is to build the identity and character of the nation.

Based on the above description, the revitalization of civic education learning in accordance with the demands and the needs of the development of national identity and character are needed to be done. One of the strategies is through the development of civic education learning in Junior High School based on the local wisdom. The students of Junior High School theoretically is on the periods of adolescence in which they were on the period of cognitive transition as well the crucial period of character development (Lickona, 1996; Malin, Liauw, and Damon, 2017). Because of that, this development is intended to produce the model of civic education learning in Junior High School based on local wisdom, as a strategy to revitalize the values of Pancasila to strengthening the character and identity of the nation. In detail, this article is limited to the description, first, the initial design of the existing civic education learning. Second, the development of the model of civic education learning. Third, the effectiveness of the model of civic education learning based on local wisdom as a strategy to revitalize the values of Pancasila for strengthening the character and identity of the nation.

\section{METHOD}

This development research was productoriented, in which the process was thoroughly described and evaluated. The product is a model of civic education learning for Junior High School based on local wisdom as a strategy to revitalize the values of Pancasila values and strengthening the character and identity of the Nation. The research site was in Surakarta due to the existence of tangible and intangible cultural construction of this city that had been fabricated by its historical process and social change (Cowherd, 2012). By the existence of cultural construction, theoretically, the civic education learning in Surakarta could be affected by the cultural construction of the city. The development 
research approach (Gall \& Borg, 2003) was chosen for its theoretical and practical excellence, especially from its research procedure that could be used systematically and cyclically to observe the needs and real situation of the Junior High Schools in Surakarta. The primary and secondary data were collected from informants, documents, places, and events (Miles, \& Huberman, 1992), consist of several techniques, namely in-depth interviews with civic education teachers, the principals of Junior High Schools in Surakarta, and the officials of the National Education Office of Surakarta. The observation technique was observing the process of civic education learning in the classroom in some Junior High School State in Surakarta, furthermore, the researcher also scrutinized the learning content and held focus group discussions.

Research stages include preliminary studies as the basis for model development. Development stage was held in collaborative and participative (Wiriaatmadja, 2005: 83), which consist of some stages: drafting the model, validity tests, limited trials, and major revisions of the draft model. The drafting of the learning model was based on the theoretical framework of the literature review, which was combined with the characteristics of the developed model and the characteristic of the civic education subject as well as the learning conditions at the junior high school. The learning model was developed based on the five learning components of Joyce (2011), encompassing syntax of learning, social system, the principle of reaction, supporting system, instructional impact, and accompaniment impact. The last stage was the learning model testing. At this stage, researcher measured the effectiveness of hypothetical models, which have been enhanced in the early stages of development, through experiments between experiment classes and control classes.

\section{RESULTS AND DISCUSSION \\ The Mapping of Civic Education Learning in Junior High School}

The data of interview and observation show the existing civic education learning and the understanding of civic education teacher. First, the objective of civic education learning is to prepare the learners to be a good and smart citizen. Teachers understand that the objectives of the civic education learning produce: (1) knowledgeable citizens, (2) possessing skills, (3) developing attitudes and values to grow a sense of nationality and love of the nation. Second, civic education is multi-dimensional, namely (1) civic education as a curricular program, (2) civic education as an academic program, and (3) civic education as a cultural social program. In the implementation of classroom learning, these three dimensions occur simultaneously. Third, civic education as a curricular program is essentially a program that is designed and taught to learners at a certain level of the educational unit. Fourth, civic education is not merely a subject in the school curriculum but rather a discipline education that has a comprehensive task. Fifth, civic education is developed in the context of community life that aims at all members of society to become good citizens in various situations and the changing times. Sixth, the existence of political euphoria in 1998 and the symbols of the new order are regarded as a latent danger, thus it is making the Pancasila Moral Education (Pendidikan Moral Pancasila) as a subject transformed into Civic Education (Pendidikan Kewarganegaraan) without Pancasila. Seventh, the coverage of material in Civic Education learning becomes one of the obstacles and difficulties for teachers in preparing the lesson plan and implementation of Civic Education learning.

In the interview, the teachers articulate the difficulties and obstacles in integrating Pancasila values and local wisdom. The difficulties and obstacles can be summarized as follows. First, the suitability of civic education materials and the time allocation contained in the curriculum is less balanced. Consequently, the learning process is monotonous, memorizing, and textual because teachers tend to use the lecture method. Second, teachers are faced with low student motivation in following civic education learning in the classroom. The students' assumption that the civic education learning tends to memorize is to be one of the factors causing low student motivation. Third, teachers are faced with students' perception that civic education learning is not very important. This was proved by the fact that civic education learning is not included in the national final examination. In addition, the civic education learning in class IX should be "taken" other subjects because of the focus of preparing national final examination. Fourth, 
in instilling the values of Pancasila and local wisdom, teachers are sometimes confront with the inconsistency between reality in the society and the subject matter. Fifth, teachers faced difficulties in applying student-centered learning methods and strategies. The reason is the low motivation of students and materials that tend to be more memorizing. Sixth, the teacher felt that the learning material of civic education is less meaningful and the compatibility between the civic education learning and the implementation in the field is not maximal yet.

Some of the preliminary findings above illustrate the strengths and weaknesses of civic education learning and are at the same time, those findings also become a rationale for developing a model of learning while integrating the values of Pancasila and the values of local wisdom for the strengthening of national identity.

The findings that the New Order government tried to correct any form of the deviation of the Old Order regime. However, the New Order tended to practice the liberalisticcapitalistic stance in managing the state, which is mean they also caught deviate from the political lines of Pancasila and the 1945 Constitution. This finding is interesting, therefore the reformation movement is considered able to correct the deviations that have been made by the New Order. However, in the present day, the meaning of Pancasila appears to be shifting back to the interests of particular power and political groups. Consequently, the promises of independence, which contains in Pancasila, have not been fully realized. Various phenomena in society should be considered by teachers and observers of civic education learning as the sign that the dynamic of national politics is always changing.

The findings of the preliminary stages of this study showed the importance of the values, which contain in each principle of Pancasila, to be implemented in civic education learning. These findings are reasonable because the character education could build the nation's personality. Education for children should include the values of nationality and love of the homeland, in which it would flourish the spirit of the struggle of the Indonesian nation to fill the independence as well as face a massive globalization. To build the global insight of young citizens within the
Indonesian context, the basic values of divinity, humanity, unity, community, social justice, competence, respect for others, freedom and peace, need to be developed (Murdiono, 2014). In civic education learning, the learners need to be helped to live based on true moral values, have a good character, and responsible for the undertaken activities.

In line with the Hutabarat's (2014) research, the findings of this study also confirmed that the implementation of civic education learning could be used to elevate the moral and characters values in junior high school students. The results of Sitompul's research revealed that the civic education learning takes an important role as a device to instill the character of junior high school students. On the other hand, Angraini (2017) supports the orientation of civic education learning, which has a substance to shape the students' moral. Angraini stated that the civic education as value education is a subject that aims to shape the students to become moral beings. In order to achieve this purpose, an appropriate learning media is needed. Basically, civic education is the value education that aims to shape the human beings to be able to respect the others according to their dignity and build perfect human. The development of the intellectual thinking or Intelligence Quotient of students through a myriad of sciences is not enough to form a perfect human. The development should be accompanied by the enactment of behavior and moral awareness.

Based on those findings and reviews, the practice of civic education learning should be combined with various value approaches. The main characteristic of civic education is not merely transferred the knowledge, but it should be oriented to educate the society to live in a good manner. Thus, the substance of learning Civics is not only knowledge but it also contains moral and values learning. Teachers are expected to understand and apply various models of value education. Furthermore, teachers are also expected to have a correct understanding of Pancasila and the concept of the unity of Indonesia. This becomes important as Supeni's finding (2015) that the understanding of Pancasila and the unity if Indonesia of pre-school teachers in Surakarta was in low level. 


\section{The Development of the Model of Civic Education Learning}

The finding of the development of civic education learning model is based on SWOT analysis, focus group discussion, and workshops from various components of educational stakeholders in Surakarta. The developments of the model of civic education learning based on the local wisdom in Junior High School of Surakarta are as follow. First, the content informal in civic education is contextual and in accordance with the social and cultural background of learners that is Javanese culture. Second, the core values of Javanese culture, which originate from the principle of respectful and harmonious, are described and mapped with the values of Pancasila and character values. Third, in preparing the learners to be smart and good citizens, the civic education learning is done by learning by doing, social problemsolving learning, socio-participatory learning, and enculturation and socialization. Fourth the learning processes as the authors mentioned in point 3, are realized by the Problem Based Learning, Project Based Learning, and value clarification approach. Fifth, the learning process through habituation and social-cultural interaction are realized by the school culture and role models of teachers, principals, and parents.

In order to achieve the objectives of civic education learning, the initial design of the model of civic education learning based on the local wisdom is developed into the learning syntax that includes some components such as the learning structure, social system, the principle of reaction, supporting system, and impact accompaniment.

\section{Learning stages}

The learning structure consists of six stages: (1) preparing the classroom and learners to follow the learning model, (2) delivering the learning materials, (3) guiding the learners to sort and choose the values and attitudes that need to be developed in freedom of opinion, (4) guiding group and class discussions, (5) evaluating and reflecting the result of discussion, (6) giving rewards and reinforcement. In the process of values strengthening, teachers act as facilitator, who explain about freedom of opinion by keeping in mind the wisdom values of Javanese culture, such as 'sepi ing pamrih rame ing gawe', 'berbudi bowo leksono', 'mikul duwur mendem jero', which are the attitudes that should be understood and developed by the learners.

\section{The social system}

In the design of the social system, the civic teacher behaves democratic and cooperative by giving freedom to the learner to express their opinion, open to accept the opinions of the learners, giving the learner the opportunity to reflect the learning material, and responsible for the ideas that appear in learning groups. In addition, civic teachers also become facilitators to support the achievement of the learning process. In this activity, teachers are required to have high creativity in order to create a fun learning atmosphere.

\section{The principle of reaction}

The principle of reaction is intended to provide learners to be convenience during the learning process in the classroom. Therefore, the learners have a high spirit, active, and able to thinking critically about various issues. The teacher's roles include are providing learning resources and media that are videos and articles related to the model, delivering the civic learning material of class VII and its relation to the principles of freedom of opinion, and guiding learners to analyze the relevance between the values and their daily life.

\section{The supporting system}

The civic education learning model based on local wisdom requires a supporting system, which consist some elements: (1) the lesson plan that contains the learning steps and the learning resources and media; (2) a group worksheet as a tool to implement the model based on the cooperative learning strategy, Problem Based Learning (PBL), and Value Clarification; (3) instrument of evaluation to measure the competence of learners and the attitude scale to measure the level of character and national identity.

\section{The impact accompaniment}

The impact accompaniment of civic learning model is designed to improve the character and identity of the Nation and as a strategy of revitalizing the values of Pancasila. The development of the civic learning model derives from contextual learning that prioritizes 
the meaningfulness of learning, in which it would only be obtained through the development of knowledge by learners, and not through indoctrination and memorization. Through these activities, the learners are not only trained to achieve academic objectives but also to achieve the social objectives. In exploring the learning resources, the learner will gain intellectual experience, while in the activities of explaining, discussing and debating of a particular topic, they will be trained to organize their ideas rationally and artistically express their opinions

Besides giving scores according to the indicators of each aspect of the learning model, the validator asked to give a conclusion regarding the feasibility of the learning model as well improvement notes. The improvement notes from validator are as follows: (1) the learning syntax needs to be adapted with the model of Problem Based Learning and Value Clarification; (2) the lesson plan should correspond with the syntax of Problem Based Learning and Value Clarification; (3) the Javanese phrase and idiom should be translated in language that can be understood by junior high school students.

The results of the development stages show the importance of teachers' roles in observing the wisdom values of the Javanese culture. This in line with Feriandi's (2017) research that reveals some idiomatic expressions such as aja dumeh, mendhem jero mikul dhuwur, or jer basuki mawa bea, have universal moral values of citizenship so those could be the character or identity of the Indonesian people that is the part of the civic culture. The Javanese culture also constructs Indonesian civic culture, because of the values that include in the civic culture are then brought by political actors (executive and legislative) to be reflected in their behavior as the representative of the people in the context of social development, politic, economy, and politic culture. It means the Javanese culture, civic culture, and politic culture have a continuous attachment.

Another substantive finding is that the values of local wisdom, which contains in manuscript, could be used as a device in civic education learning in junior high school. This is supported by Ramdani \& Sapriya`s (2017) research that the values, which contains in the Amanat Galunggung manuscript, could be integrated into the civic education learning because it corresponds to the learning objectives. The integration of the values of Amanat Galunggung manuscript in the civic education learning, especially in Darul Falah 2 Junior High School, is implemented by studying and incorporating the value of local wisdom in each of the basic competencies.

In the context of the Surakarta society, the values of the local wisdom of Javanese culture need to be explored more deeply, thus, it can be socialized to the younger generation. The local wisdom values, such as gotong royong or mutual assistance, tepo seliro or tolerance, and solidarity, are very important to be imparted to the learners through civic education learning. This is consistent with Ghufron's (2017) research, who states that the relevant learning approach to be used for to cultivate the cultural values in Yogyakarta is through the non-directional learning of Carl Rogers's version. The values of local wisdom essentially are the core of Pancasila values. Therefore, civic education learning based on local wisdom is expected to produce the learners, who have are cultured as well as have Indonesian personality.

Based on the aspect of assessment and 32 indicators that had been validated, obtained an average value of 4.18 . The indicators represent the four components of learning model, encompassing the indicator of the learning stages, the social system, the teacher and student role, the supporting system, and the nurture effects (Joyce, Weil, and Calhoun, 2011). This shows that the developed learning model is well categorized. The finding that the lesson plan is needed to develop in some procedure that leads to the cooperative learning stage, Project Based Learning, and Value clarification is interesting. It because of the Problem Based Learning is developed to support the students to enhance the problem-solving skills and the intellectual skills, real experiences or stimuli and become autonomous and independent learners (Ibrahim, 2000). The aspects, which are validated by the expert includes the format of the lesson plan, content, and language of the lesson plan. The aspects are outlined in the revised lesson plan, in which the researchers collaborate with the subject teacher by attempting to refine the steps, especially in terms of content. Overall, the percentage of the scale that has been made is can be categorized in good category $53.33 \%$ 
and very good $40 \%$. Based on the results of the assessment, the lesson plan is classified in a good category, so it is feasible to be used in the civic education learning process.

The civic education learning model based on local wisdom requires good supporting system, such as syllabus, learning implementation plan (lesson plan), student worksheet, and assessment tools. The tools contain learning steps, learning resources, learning media to the teacher's value system. The importance of instructional tools is also expressed by Mannan, Sopyan, and Sunarno (2015), whose states that local wisdombased learning is one of the innovations in the development of learning tools. The learning tools, which are developed include a syllabus, lesson plan, student worksheet, and learning outcomes that are integrated with local wisdom in Kandri area, Gunungpati.

The local wisdom of Javanese culture is packaged in an interesting way in shaping the character values of learners. It just takes the skills of teachers in assembling the value of local wisdom so that in accordance with the achievements of learning Civics. This is supported by Fajarini (2014) research, which states that digging and preserving various elements of local wisdom results in an effective function in character education while conducting studies and enrichment with new of wisdom.

\section{The Effectiveness of Civic Education Learning Model Based on the Local Wisdom}

The results of the effectiveness of civic education learning model based on local wisdom as revitalization strategy of Pancasila values and improve the character and identity of Nation refers to Nieveen (1999) criteria, which observe the validity, practicality, and effectiveness of the model. The first aspect is the problem of the validity of the model of civic education learning based on local wisdom. The model is classified to be valid if it meets the criteria: (1) at least two of the three experts (validators) state that the model is based on a strong theoretical basis; (2) at least two of the three validators state that the model components are consistently interrelated; (3) the test results show that the components are interrelated.

The result of expert and practitioner validation on the limited trial phases show that the initial draft of the civic learning model had met the requirements of strong theoretical basis and interrelatedness of components in the learning model. The interrelatedness of the learning components is proved by the results of observation in the first test and the second test as well as in the validation test. The design of planning, implementation, and evaluation are interrelated. Between the syntax of learning to each other are also interrelated. Between teachers' activities with learners' activity are interrelated, between the activities of learners ingroup activities with the activities of learners in the activities of individuals are also interrelated. Based on the test results, the civic learning model based on the local wisdom has fulfilled the validity requirements of a feasible learning model.

The second aspect is about the practicality of the civic learning model based on the local wisdom. The learning model is considered practical because it meets the criteria: (1) at least two of the three experts give consideration that the learning model can be applied in class; (2) the teacher states that they were able to apply the learning model in front of the class; (3) the level of implementation of the learning, the model is included in the high category. The results of a limited trial show that the validator of the practitioner, who is the civic teacher and asked to validate, had stated that the draft of civic learning model is feasible and applicable in the classroom.

The results of the limited trial showed that the observation of teacher activity indicates very well criteria. The results of the analysis of student's activity show very good and average mastery of competence or learning result of mastery learning by 70 and indicator of learner who reaches mastery reach $75 \%$. The increase of the score of national identity reached $80 \%$. Similarly, with the results of extensive trials, the results of observation of teacher's activities, learners, and learning outcomes of learners show an average value above 70 . The criteria for the practicality of learning model have been fulfilled so it can be concluded that the learning model could be practically applied in the classroom.

The third aspect is about the effectiveness of civic learning model based on local wisdom. The model is categorized to be effective because it meets 4 of the 5 following criteria: (1) average of activity on the task of learners at least by 
$90 \%$; (2) the average of learners activity is at least $40 \%$; (3) there is a tendency to increase test scores; (4) more than $50 \%$ of learners respond positively; and (5) the teacher responds positively to the model.

The effectiveness of the model of civic education learning could be seen in the development of learners' activity, teachers' activity, as well as teacher and learner's response to the implementation of the learning model. The results of the teacher and student's activity assessment in the implementation of the model at each stage of the test have progressed and reach a very good standard. Similarly, the tendency to improve students' learning outcomes in trials and extensive trials shows an increasing trend in the components of competence, character and national identity. Thus, the implementation of civic learning model based on the local wisdom, especially in State Junior High School 10 Surakarta and State Junior High School 21 Surakarta have been running in accordance with the developed model and able to increase the students' character score and the students' national identity score as much as $80 \%$. The model is able to increase learning mastery of at least $75 \%$. Therefore, it can be concluded that the model of civic education learning based on the local wisdom had fulfilled the requirements of the effectiveness of a learning model.

The utilization of local wisdom values, which is adopted in the civic education learning, is often done by the teachers. In fact, the value of local wisdom appropriate to be integrated with civic education learning. The result of the effectiveness test of the learning model is in line with the results of Mannan, Sopyan, and Sunarno's (2015) research. They stated that based on the observations using several indicators, the average gain for the first meeting until the third meeting was 0.33 . The analysis of character indicates a moderate increase so it can be said that learning tools based on local wisdom can improve the students' character.

Sitompul (2014) does another research that supported this research. The results of his research concluded that there are 10 values of characters that have been applied in civic learning in Junior High School State 37 Medan, namely religious, honest, curiosity, tolerance, nationalism, reading, discipline, environmental care, social care, and responsibility. Meanwhile, there are nine values of characters that have been applied in civic learning Junior High School Budi Murni 1 Medan, namely religious, honest, democracy, curiosity, peace love, tolerance, the spirit of nationalism, love to read, and love the homeland. Thus, the civic education learning can be used as a device to apply character education to junior high school students.

\section{CONCLUSION}

The conclusions of the research are briefly described as follows. First, there are strength, weaknesses, chances, and perils in civic education learning. Some obstacles that faced by the civic education teachers are the suitability of civic education materials with less balanced time allocation, low student motivation in following the civic education learning in the classroom, the students' perception that civic lesson is not very important, the reality of society is not in accordance with the subject matter of civics, and the implementation of student-centered learning methods and strategies.

Second, the initial design of the civic learning model based on the local wisdom is in accordance with the syntax of learning that includes the structure of learning, social system, principles of reaction, supporting systems, and impact accompanist. The structure includes several stages. The social system is embodied in the roles of teachers who are democratic and cooperative by giving students the freedom to argue. The principle of reaction is realized with the teacher to facilitate the learners during the learning process. The supporting system of the lesson plan acts as the tool to support the learning model and evaluation sheet to measure the competence of learners ' competence and attitude scale to measure character and national identity. The impact of companions based on contextual learning that prioritizes the meaningfulness of learning.

Third, the effectiveness of civic education learning model based on the local wisdom in improving the character and identity of the Nation as a strategy of revitalizing Pancasila values is shown by the fulfillment of criteria of validity, practicality, and effectiveness. The effectiveness test at State Junior High School 10 Surakarta and State Junior High School 21 Surakarta has been run in accordance with the developed model and able to increase the character score 
and the national identity score as much as $80 \%$. The model of civics learning education based on local wisdom can improve learning mastery of at least $75 \%$.

Furthermore, the recommendations are submitted to the civic education teachers. Since the civic learning model based on local wisdom is able to create a meaningful and fun learning, the civic teachers should improve their learning materials with the socio-cultural context of the learners. The school as a gathering place of learners of various groups, races, cultures, and gender are expected to be able to transform the noble values of religion that are considered 'absolute' and cultural values that are relative to the core values of character education. For the learners, one of the learning characteristics of this learning model is student-centered. The greater the learners engage in learning activities would result the greater the learners to do learning activities. In this case, the teacher is expected to improve the innovation and skills in designing the classroom, thus, the learners not only learn about the concepts and principles but also experience the process of learning about self-direction, responsibility, and social communication.

\section{ACKNOWLEDGMENT}

This article was written on base of the results of a Competing Grant Research on "The Development of Civic Education Learning Model in Junior High School Based on the Local Wisdom as a Strategy of Revitalizing Pancasila Values for Strengthening the Character and the National Identity" based on the agreement of research implementation number 194.2/A.3-III/ LPPM/V/2014, May 17, 2014. Therefore, the authors would like to express our gratitude and high appreciation to the Director of DP-2M of the Directorate General of Higher Education of the Ministry of Education and Culture of the Republic of Indonesia, who has provided funds. The rector of UMS and the Chairman of LPPM UMS, who gave the approval for this study. Civics teachers of Junior High School in Surakarta, especially for civic teachers of State Junior High School 10 Surakarta and State Junior High School 21 Surakarta, the Head of the junior high school, and the Official of Dikpora Surakarta. On this occasion, the authors also would like to say thank you to the editors of the
Jurnal Cakrawala Pendidikan from the Institute of Community Service of the State University of Yogyakarta who has the pleasure to publish this article.

\section{REFFERENCES}

Angraini, R. 2017. Karakteristik Media yang Tepat dalam Pembelajaran Pendidikan Kewarganegaraan sebagai Pendidikan Nilai. Journal of Moral and Civic Education, 1(1), 14-24.

Budimansyah, D. \& Suryadi, K. 2008. PKn dan Masyarakat Multi-kultural. Bandung: Prodi PKn-Sekolah Pascasarjana-UPI Bandung.

Cowherd, R. 2012. The cultural construction of Surakarta, Java. In The Emerging Asian City: Concomitant Urbanities and Urbanisms (pp. 66-74). Taylor andFrancis. https://doi.org/10.4324/9780203094655

Fajarini, U. 2014. Peranan Kearifan Lokal dalam Pendidikan Karakter. Jurnal SOSIO DIDAKTIKA:Social Science Education Journal, 1(2), 123-130.

Feriandi, Y.A. 2017. Revitalisasi Moral Kewarganegaraan dalam Ungkapan Jawa sebagai Sumber Pembentukan Civic Culture dan Politic Culture. Jurnal Civics: Media Kajian Kewarganegaraan, 14(2), 176-182.

Gall, M.D, Gall, Joyce P., \& Borg, W.R. (2003). Educational Research, An Introduction (Seventh Ed.). Boston: Allyn and Bacon.

Geertz, C. (1963). The Interpretation of Culture. New York: Basic Books.

Ghufron, A., Budiningsih, C.A., \& Hidayati. (2017). Pengembangan Pembelajaran Berbasis Nilai-nilai Budaya Yogyakarta di Sekolah Dasar. Jurnal Cakrawala Pendidikan, XXXIV(2), 309-319.

Hutabarat, R. C. (2014). Model Pendidikan Karakter melalui Pembelajaran PKn di Sekolah Menengah Pertama Kelas VII SMPN 37 dan SMP Budi Murni 1 Medan 
T.P 2012/2013. Jurnal Saintech 6(2), 5458.

Ibrahim, M., Rachmadiarti, F., Nur, M. 2000. Pembelajaran Kooperatif. Surabaya: Universitas Negeri Surabaya Press.

Joyce, B., Weil, M., \& Calhoun, E. 2011. Model of Teaching. London: Allyn and Bacon.

Kalb, D. 2006. Uses of Local Knowledge. In The Oxford Handbook of Contextual Political Analysis. Oxford University Press. https://doi.org/10.1093/oxfordhb/ 9780199270439.003.0031

Lickona, T. 1996 Eleven Principles of Effective Character Education, Journal of Moral Education, 25:1, 93-100, DOI: $10.1080 / 0305724960250110$

Malin, H., Liauw, I., \& Damon, W. 2017. Purpose and Character Development in Early Adolescence. Journal of Youth and Adolescence, 46(6), 1200-1215. https:// doi.org/10.1007/s10964-017-0642-3

Mannan, M. N., Sopyan, A, \& Sunarno. 2007. Pengembangan Perangkat Pembelajaran Berbasis Kearifan Lokal untuk Mengembangkan Karakter Positif Siswa SD. Jurnal Inovasi dan Pembelajaran Fisika, 2(2), 141-146.

Miles, M. B. \& Huberman, A. M. 1992. Qualitative Data Analysis. Beverly Hills: Sage Publication.

Murdiono, M. 2014. Pendidikan Kewarganegaraan Untuk Membangun Wawasan Global Warga Negara Muda. Jurnal Cakrawala Pendidikan, 23(3), 349-357.

Nieveen, N. 1999. Design Approaches and Tools in Education and Training. London: Kluwer Academic Published.
Rahyono, F. X. (2009). Kearifan Budaya dalam Kata. Bandung: Wedatama Widya Sastra.

Ramdani, Y. A. \& Sapriya 2017. Integrasi Nilai Kearifan Lokal Berbasis Naskah Amanat Galunggung pada Pembelajaran Pendidikan Kewarganegaraan. Jurnal Masyarakat, Kebudayaan \& Politik, 30(4), 418-427.

Samsuri, S. 2009. Objektivikasi Pancasila sebagai Modal Sosial Warga Negara Demokratis dalam Pendidikan Kewarganegaraan. Jurnal Acta Civicus, 2(2), 169-180.

Supeni, S. 2015. Pengembangan Model Internalisasi Pendidikan Karakter Pancasila pada Guru Pendidikan Anak Usia Dini. Jurnal Cakrawala Pendidikan, XXXIV (1), 118127.

Undang-Undang Republik Indonesia No. 20 Tahun 2003. Sistem Pendidikan Nasional. Bandung: Citra Umbara.

Winarno, W. 2017. "Aktualisasi Pendidikan Pancasila dan Kewarganegaraan untuk Memperkuat Sendi-sendi Kehidupan Berbangsa". Proceding Seminar Nasional Asosiasi Profesi Pendidikan Pancasila dan Kewarganegaraan (AP3KnI) Jawa Tengah 2017. Cetakan I. Edisi I. Desember 2017.

Winataputra, U. S. 2001. "Jati Diri Pendidikan Kewarganegaraan sebagai Wahana Pendidikan Demokrasi”. Disertasi. Bandung: Universitas Pendidikan Indonesia.

Wiriaatmadja, R. 2005. Metode Penelitian Tindakan Kelas. Bandung: PPS UPI Bandung dan Remaja Rosdakarya. 